Supplement of Earth Surf. Dynam., 8, 1053-1065, 2020

https://doi.org/10.5194/esurf-8-1053-2020-supplement

(c) Author(s) 2020. This work is distributed under

the Creative Commons Attribution 4.0 License.

(c) (1)

Supplement of

\title{
GERALDINE (Google Earth Engine supRaglAciaL Debris INput dEtector): a new tool for identifying and monitoring supraglacial landslide inputs
}

William D. Smith et al.

Correspondence to: William D. Smith (w.d.smith2@newcastle.ac.uk)

The copyright of individual parts of the supplement might differ from the CC BY 4.0 License. 


\subsection{Randolph Glacier Inventory (RGI) v6.0 errors}

The Randolph Glacier Inventory v6.0 (Pfeffer et al., 2014) is a global dataset of digitised glacier outlines, excluding the ice sheets of Greenland and Antarctica. These outlines were digitised from images acquired between 1943 and 2014. This large temporal array of images introduces a variety of dataset errors, due to rapid glacial thinning and retreat, in response to climatic change over the last century. GERALDINE's delineation of new debris additions on glaciers is impacted by these discrepancies.

We run GERALDINE for the year 2018 over the Columbia glacier, a glacier which has undergone unprecedented retreat over the last three decades, to demonstrate RGI impacts (Figure S1). RGI outlines in this region were digitised from imagery acquired in 2009 but the glacier has retreated $\sim 8 \mathrm{~km}$ since then, losing $46.9 \mathrm{~km}^{2}$ at its tongue. Clean ice is 'found' in the now ice-free area, owing to ice melange/icebergs, and debris is 'found' due to the dark, unreflective ocean surface. We advise caution with the delineation of new debris additions near the terminus of marine-terminating glaciers, if they have recently undergone substantial retreat. Glacial thinning/down-wasting can also cause discrepancies in GERALDINE outputs. All tributaries of the western trunk of the Columbia glacier have undergone down-wasting, exposing valley walls. GERALDINE delineates this down-wasting and subsequent valley wall exposure as surficial debris, represented by each glacier having thick lateral 'debris' bands (Figure S1B). These are likely to expand with further glacial mass wastage, until RGI outlines are updated in $\mathrm{v} 7.0$. 

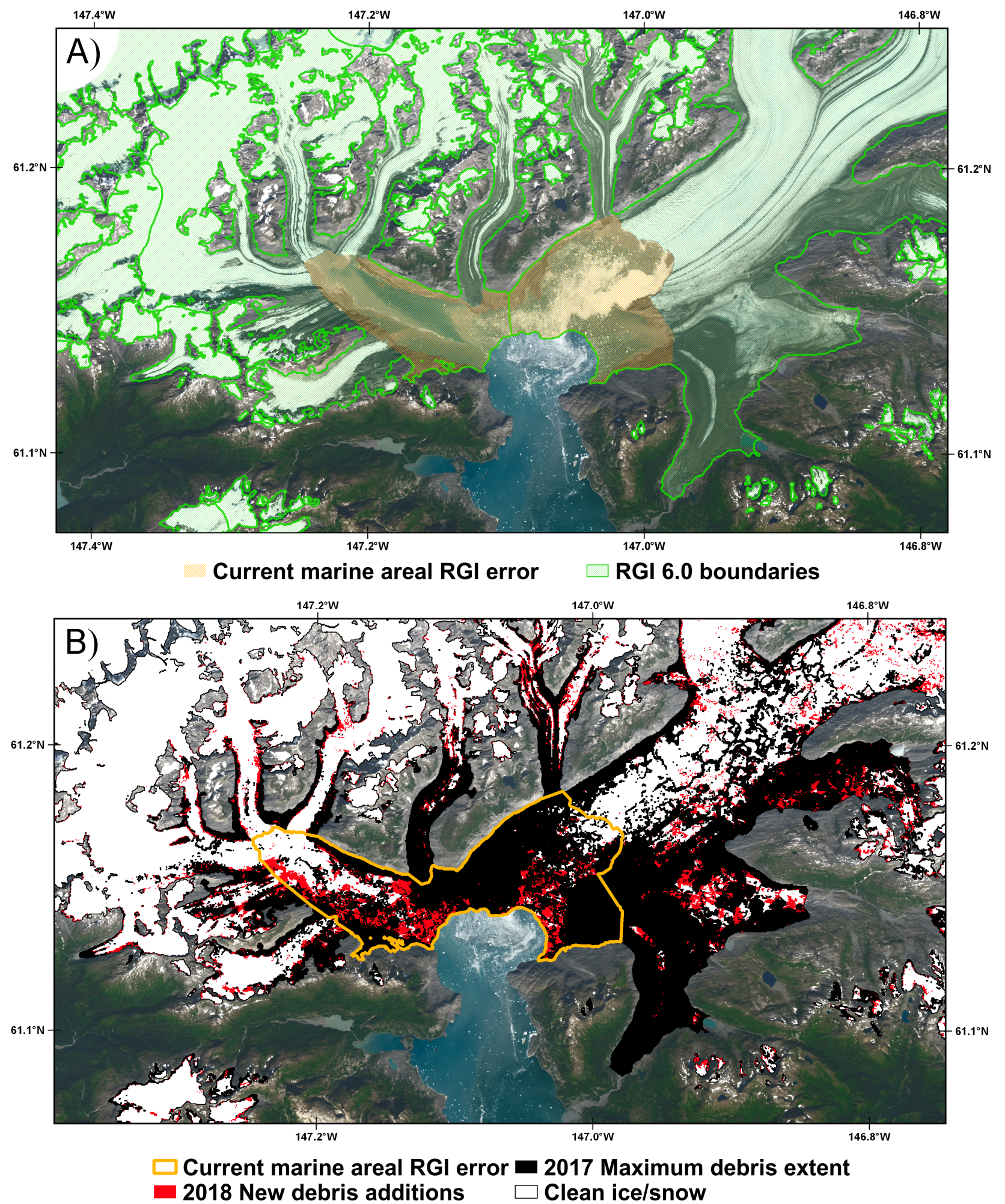

Figure S1: Retreat of the Columbia Glacier, Alaska and the impact on RGI v6.0 outline accuracy. A) RGI v6.0 glacier outlines (green) and the area, which is no longer glaciated (orange). B) GERALDINE new debris results in this area for 2018. Landsat 8 background image from 2019-08-20. 


\subsection{Cloud mask threshold validation}

To determine the optimum threshold for cloud masking we chose 13 rock avalanches (RA) from the validation dataset, to validate different thresholds against. The high prevalence of RAs in Alaska meant all events chosen for cloud mask threshold validation occurred in the region, with nine occurring in Glacier Bay National Park (Coe et al., 2018) and four occurring in the eastern Alaska Range, in particular the area around Mt Hayes (Jibson et al., 2006) (Table 1). This selection incorporated two areas with different climatic regimes (marine vs continental climate) and a wide temporal coverage incorporating all Landsat satellites, with particular focus on the current constellation, due to the tool's main use for aiding RA detection in the present day.

Table 1: Rock avalanches (RA) used for cloud mask threshold validation

\begin{tabular}{|c|c|c|c|c|c|c|}
\hline RA Name & Region & Year & Latitude & Longitude & Satellite & $\operatorname{Area}\left(\mathrm{km}^{2}\right)$ \\
\hline 2 & $\begin{array}{l}\text { Glacier Bay } \\
\text { National Park }\end{array}$ & 1986 & 58.794 & -137.354 & Landsat $4 / 5$ & 0.025 \\
\hline 10 & $\begin{array}{l}\text { Glacier Bay } \\
\text { National Park }\end{array}$ & 1986 & 58.830 & -137.502 & Landsat $4 / 5$ & 1.371 \\
\hline 14 & $\begin{array}{l}\text { Glacier Bay } \\
\text { National Park }\end{array}$ & 1986 & 58.647 & -137.058 & Landsat $4 / 5$ & 0.544 \\
\hline $\begin{array}{l}\text { Black Rapids } \\
\text { Glacier W }\end{array}$ & $\begin{array}{l}\text { Eastern Alaska } \\
\text { Range } \quad(\mathrm{Mt} \\
\text { Hayes) }\end{array}$ & 2002 & 63.472 & -146.263 & Landsat $5 / 7$ & 1.136 \\
\hline $\begin{array}{l}\text { McGinnis Peak } \\
\text { Glacier S }\end{array}$ & $\begin{array}{l}\text { Eastern Alaska } \\
\text { Range } \quad(\mathrm{Mt} \\
\text { Hayes) }\end{array}$ & 2002 & 63.547 & -146.198 & Landsat 5/7 & 1.321 \\
\hline $\begin{array}{l}\text { Black Rapids } \\
\text { Glacier E }\end{array}$ & $\begin{array}{l}\text { Eastern Alaska } \\
\text { Range } \quad(\mathrm{Mt} \\
\text { Hayes) }\end{array}$ & 2002 & 63.461 & -146.167 & Landsat $5 / 7$ & 1.612 \\
\hline $\begin{array}{l}\text { Black Rapids } \\
\text { Glacier M }\end{array}$ & $\begin{array}{l}\text { Eastern } \\
\text { Range } \\
\text { Hayes) }\end{array} \quad$ (Mt & 2002 & 63.466 & -146.226 & Landsat $5 / 7$ & 1.950 \\
\hline 7 - John Hopkins & $\begin{array}{l}\text { Glacier Bay } \\
\text { National Park }\end{array}$ & 2015 & 58.769 & -137.269 & Landsat $7 / 8$ & 3.375 \\
\hline 11 & $\begin{array}{l}\text { Glacier Bay } \\
\text { National Park }\end{array}$ & 2015 & 58.626 & -137.281 & Landsat $7 / 8$ & 1.223 \\
\hline 23 & $\begin{array}{l}\text { Glacier Bay } \\
\text { National Park }\end{array}$ & 2015 & 58.622 & -137.275 & Landsat $7 / 8$ & 0.586 \\
\hline 24 - Lamplugh & $\begin{array}{l}\text { Glacier Bay } \\
\text { National Park }\end{array}$ & 2016 & 58.779 & -136.888 & Landsat $7 / 8$ & 19.174 \\
\hline 26 & $\begin{array}{l}\text { Glacier Bay } \\
\text { National Park }\end{array}$ & 2016 & 58.635 & -137.018 & Landsat $7 / 8$ & 0.231 \\
\hline 27 & $\begin{array}{l}\text { Glacier Bay } \\
\text { National Park }\end{array}$ & 2016 & 58.852 & -137.247 & Landsat $7 / 8$ & 0.146 \\
\hline 28 & $\begin{array}{l}\text { Glacier Bay } \\
\text { National Park }\end{array}$ & 2016 & 58.844 & -137.345 & Landsat $7 / 8$ & 0.707 \\
\hline
\end{tabular}

Five different cloud thresholds were tested: $10 \%, 20 \%, 30 \%, 50 \%$ and $90 \%$, to investigate their influence on highlighting new RA events. GERALDINE was run for the year of the event, or in the case of the eastern Alaska Range RAs, the year after the event, because these RAs occurred in November 2002 and therefore appeared in no Landsat imagery during that year. New debris layers generated by GERALDINE were downloaded, and the area of new debris 
detected in the location of RAs, was compared to digitised RA outlines from the same year. A cloud mask threshold of $20 \%$ highlighted the largest area of new RAs, delineating $60.6 \%$ of RA area (Figure S2). The 10\% cloud threshold masked too much of each image, inhibiting its ability to highlight new debris. Higher thresholds did not mask enough cloud discrepancies out of images resulting in misclassification of cloud as debris in previous year debris extents. This misclassification prevented GERALDINE from highlighting new debris because debris was already present in the previous year. GERALDINE therefore utilises a $20 \%$ cloud threshold by default.

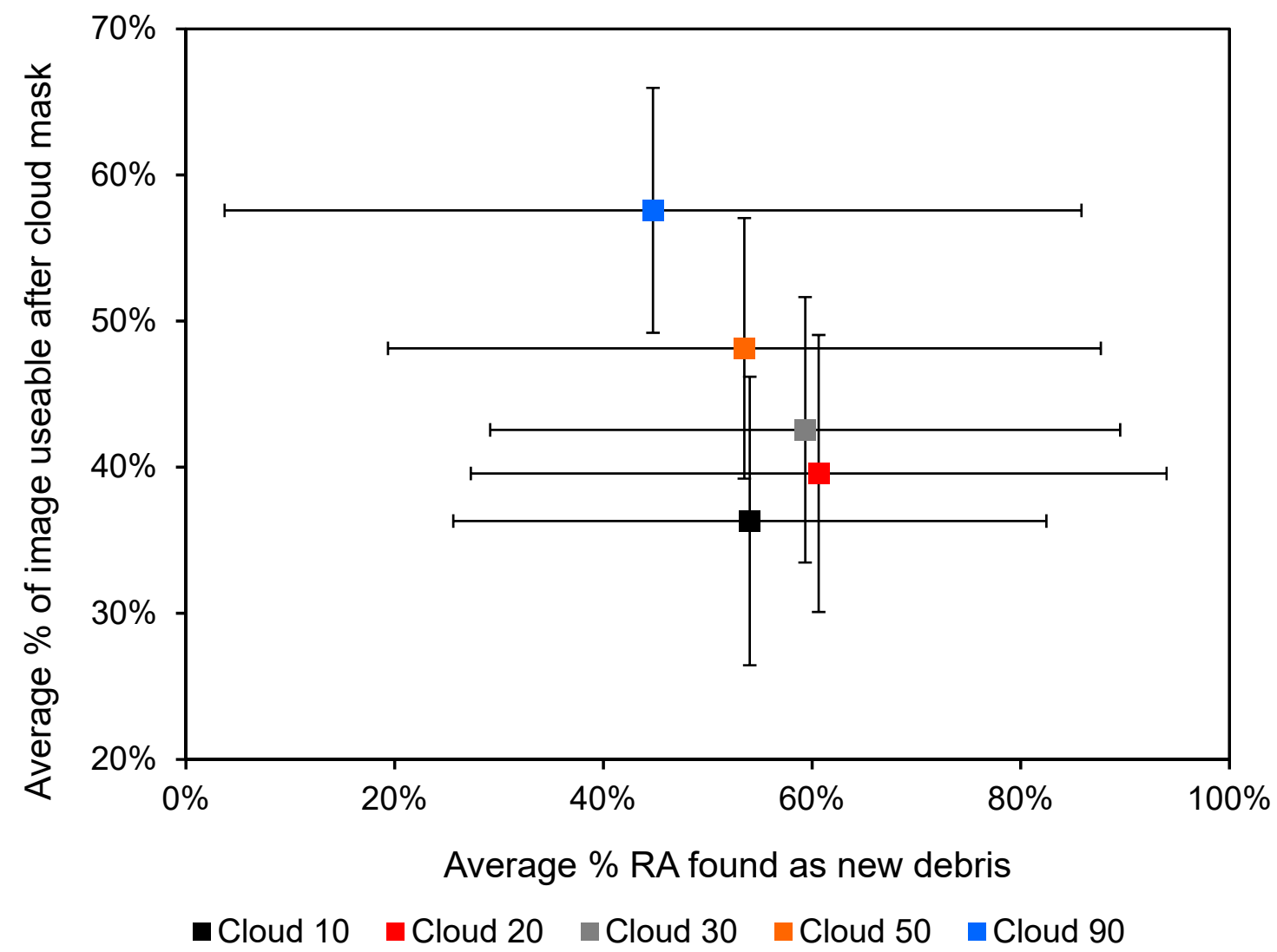

Figure S2: Mean area of RA highlighted as new debris by GERALDINE, and mean area of each Landsat image available after cloud masking, for five different cloud thresholds. Error bars represent standard deviation of the mean.

We provide both good and bad examples of cloud mask performance on a single Landsat image in Figures S3 and S4, respectively. Figure S3 showcases the cloud masks ability to accurately mask cloud that is obscuring part of the Lamplugh RA, removing it from further analysis (Figure S3). However, occasionally it can suffer over debris cover in some areas (Figure S4), due to the optical and temperature similarities of the debris to cirrus clouds. This has similarly been found in Antarctica with sunlit rock misclassification as cloud (Burton-Johnson et al., 2016). However, the image stack methodology used by GERALDINE helps to negate these cloud masking discrepancies. 

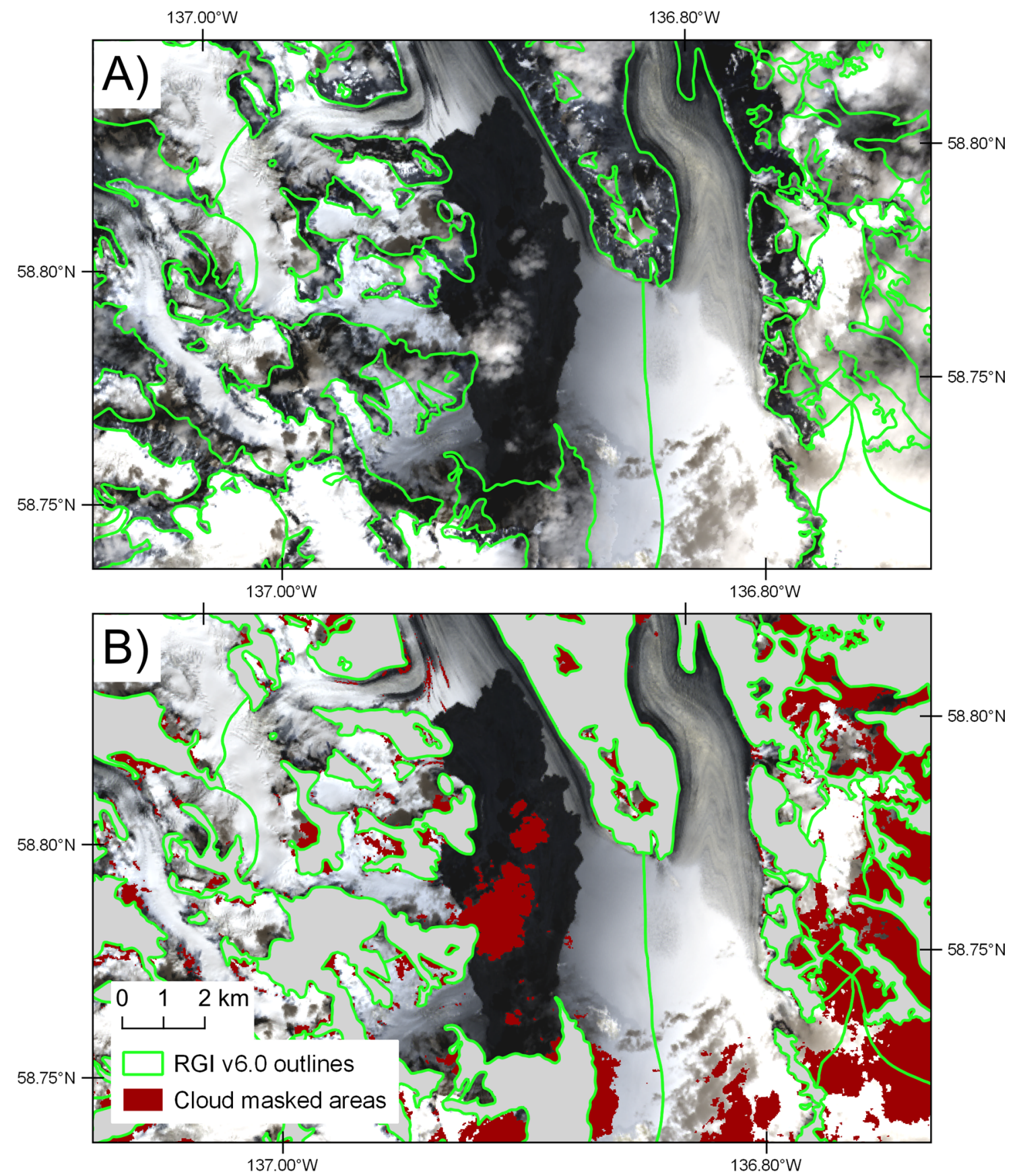

Figure S3: A) Original Landsat image (LC08_060019_20160729), B) Cloud masked Landsat image. Masking shows good ability to eliminate cloud pixels from scenes. 


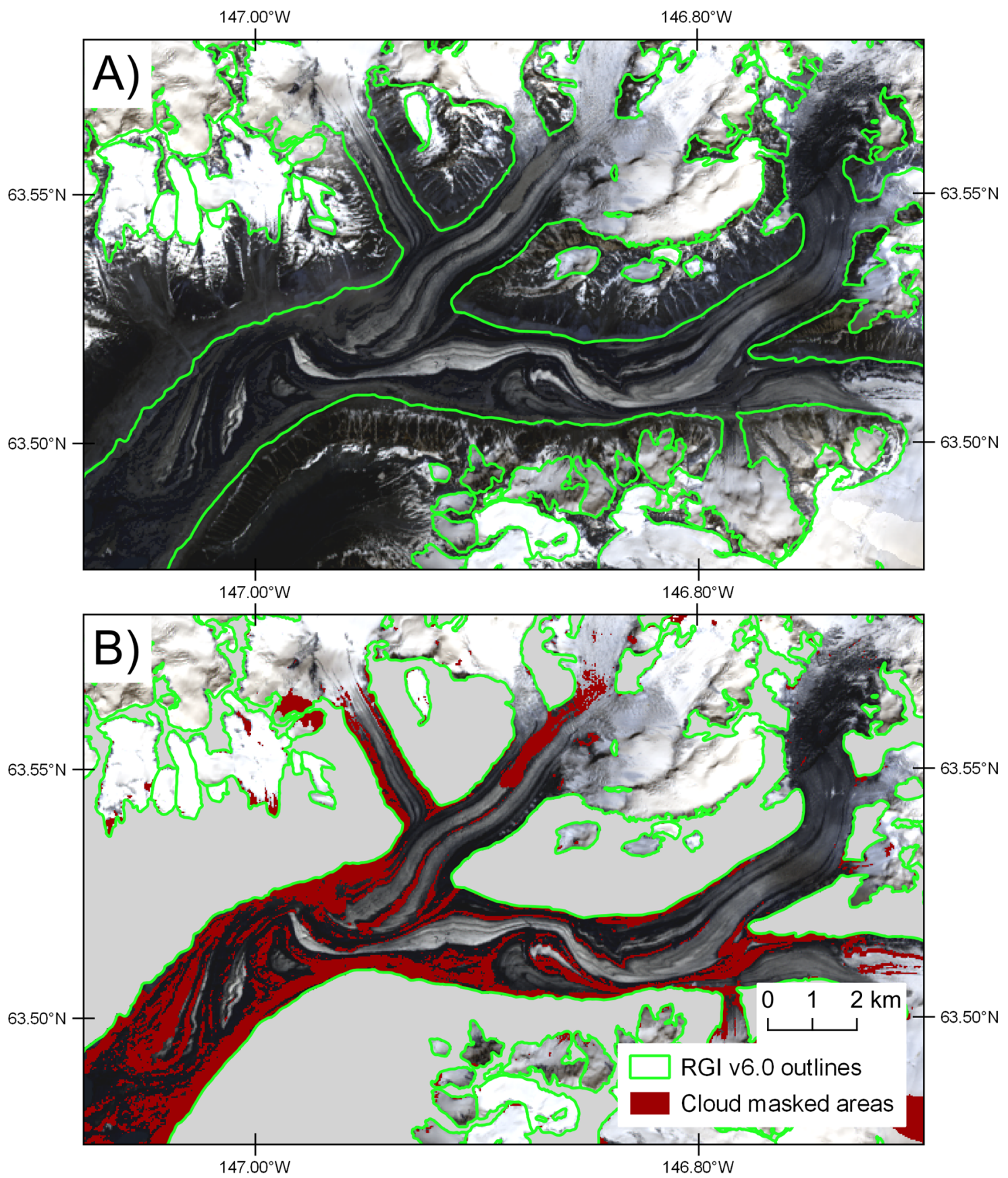

Figure S4: A) Original Landsat image (LC08_067016_20180704), B) Cloud masked Landsat image. Masking shows poor ability to eliminate cloud pixels from scenes, with misclassification of lighter debris as cloud. 


\subsection{Global distribution of validation RAs}

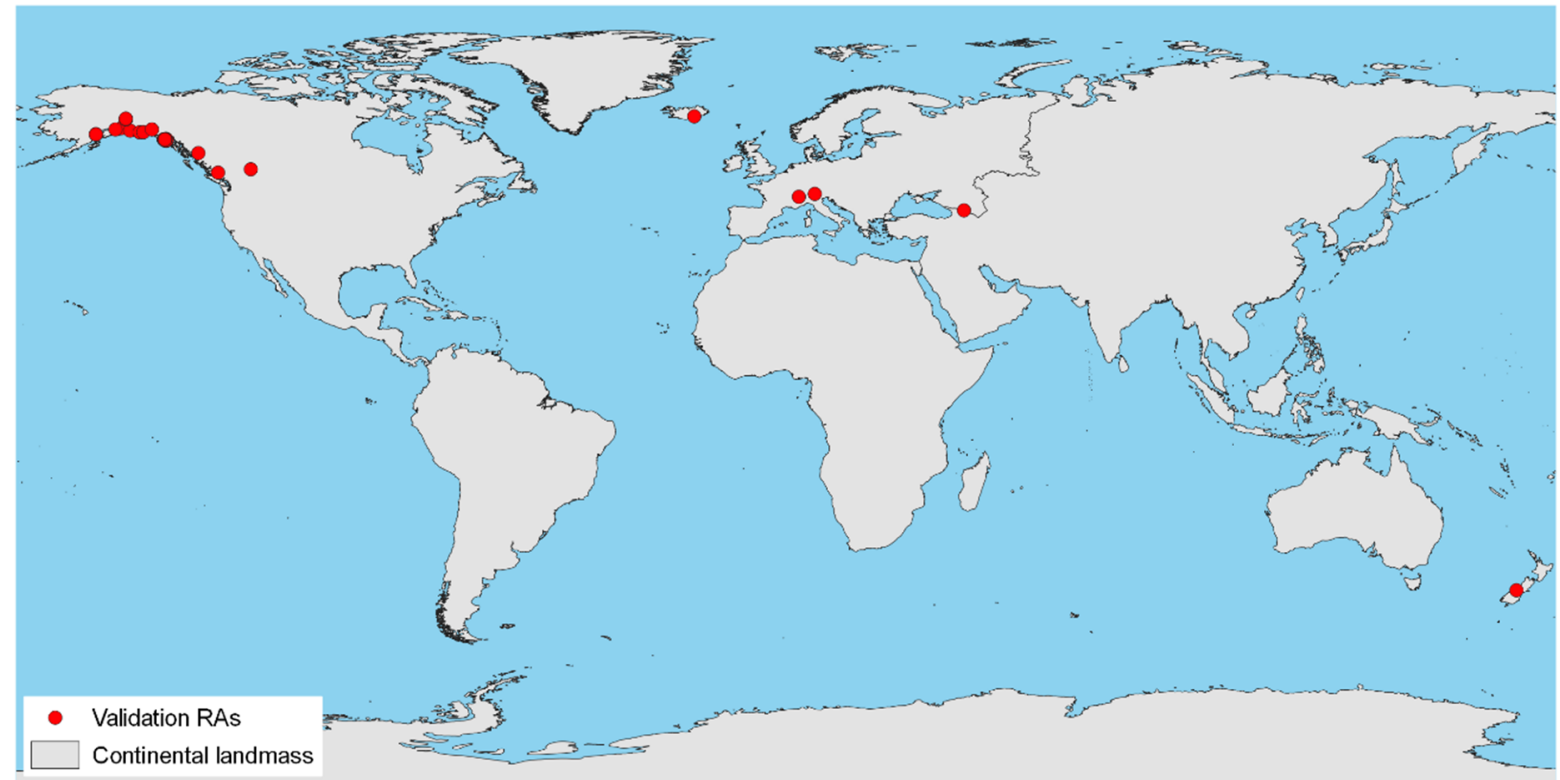

Figure S5: Global distribution of RAs used for GERALDINE validation (48 in total). 


\subsection{GERALDINE User Guide}

The tool is freely available to use at (https://code.earthengine.google.com/87b7fdf47b8d550a7c6ed85a2ebd7ad8) but requires a Google account authorized to use Google Earth Engine (GEE), which is free of charge if used for research and educational purposes (sign up for Google account here: https://accounts.google.com/signup/v2/webcreateaccount?flowName=GlifWebSignIn\&flowEntry=Sig nUp and register for GEE access here: https://earthengine.google.com/). Exporting of tool outputs requires a Google Drive account, which is complementary with the Gmail account required to sign up for GEE. The tool is open access and GUI (graphical user interface) driven. Tutorials on how to use Earth Engine are available at https://developers.google.com/earth-engine/ but here we will provide instructions on how to use our tool to detect supraglacial landslide deposits.

\section{Step 1:}

Open v1.1 of GERALDINE (the version described in the manuscript) by clicking on this link: https://code.earthengine.google.com/87b7fdf47b8d550a7c6ed85a2ebd7ad8 or access the latest version of GERALDINE at https://doi.org/10.5281/zenodo.3524414 (if using the latest version these instructions may differ slightly).

\section{Step 2:}

You will be greeted by the start page shown below. Click 'New project' to start analysis.

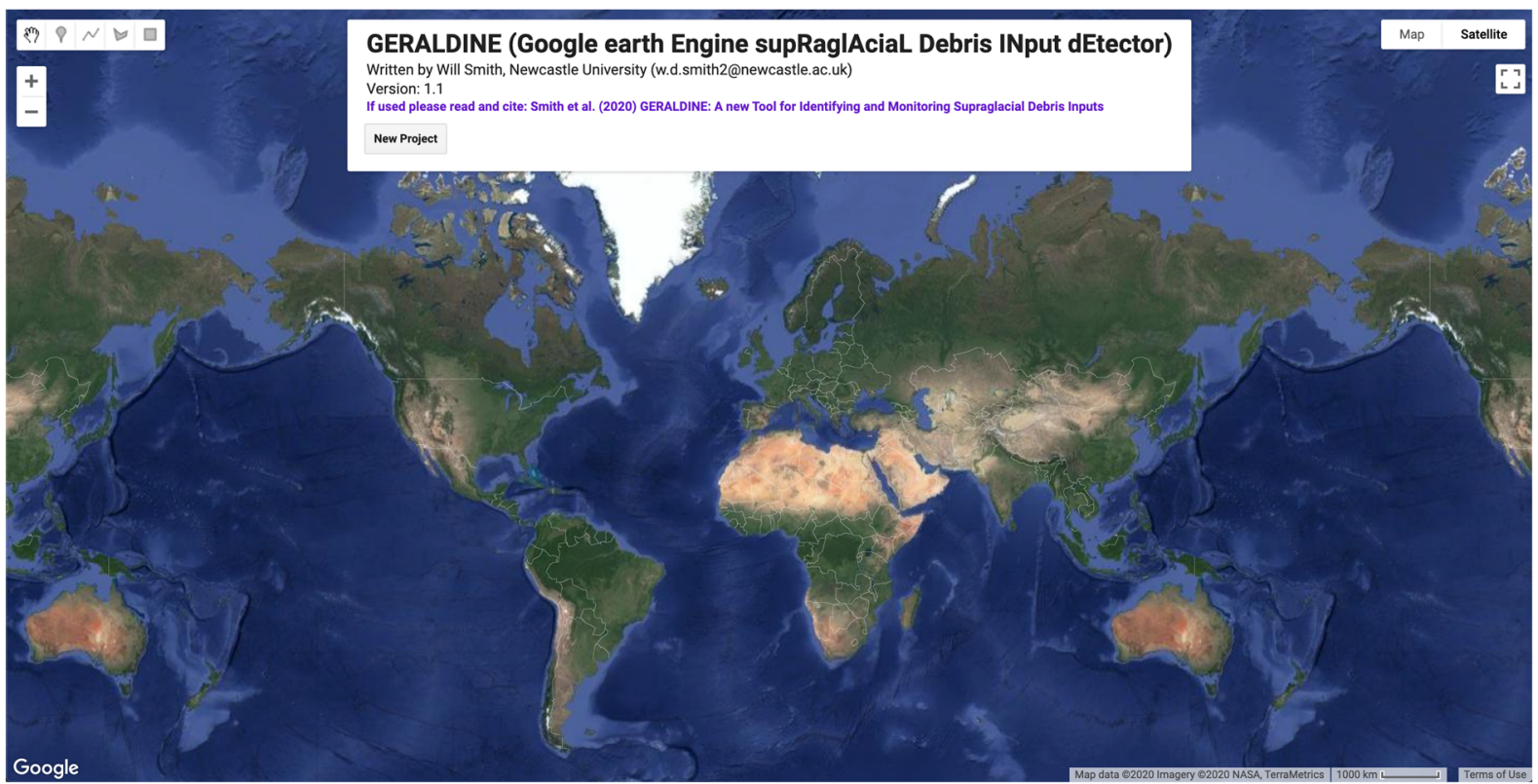

Step 3:

Draw region of interest (ROI) by zooming in and clicking around an area to draw a polygon (Note: large ROIs and time periods that involve $>800$ images can be slow to load as they are calculated 'on the fly' in the map window). Alternatively, upload a shapefile of your ROI to Google Earth Engine (see: https://developers.google.com/earth-engine/importing for more information) and specify the GEE file path, which can be found by sliding down the top panel and navigating to the 'Assets' tab in the top left hand panel (highlighted by red box in image below). Click OK button when your ROI is defined. 


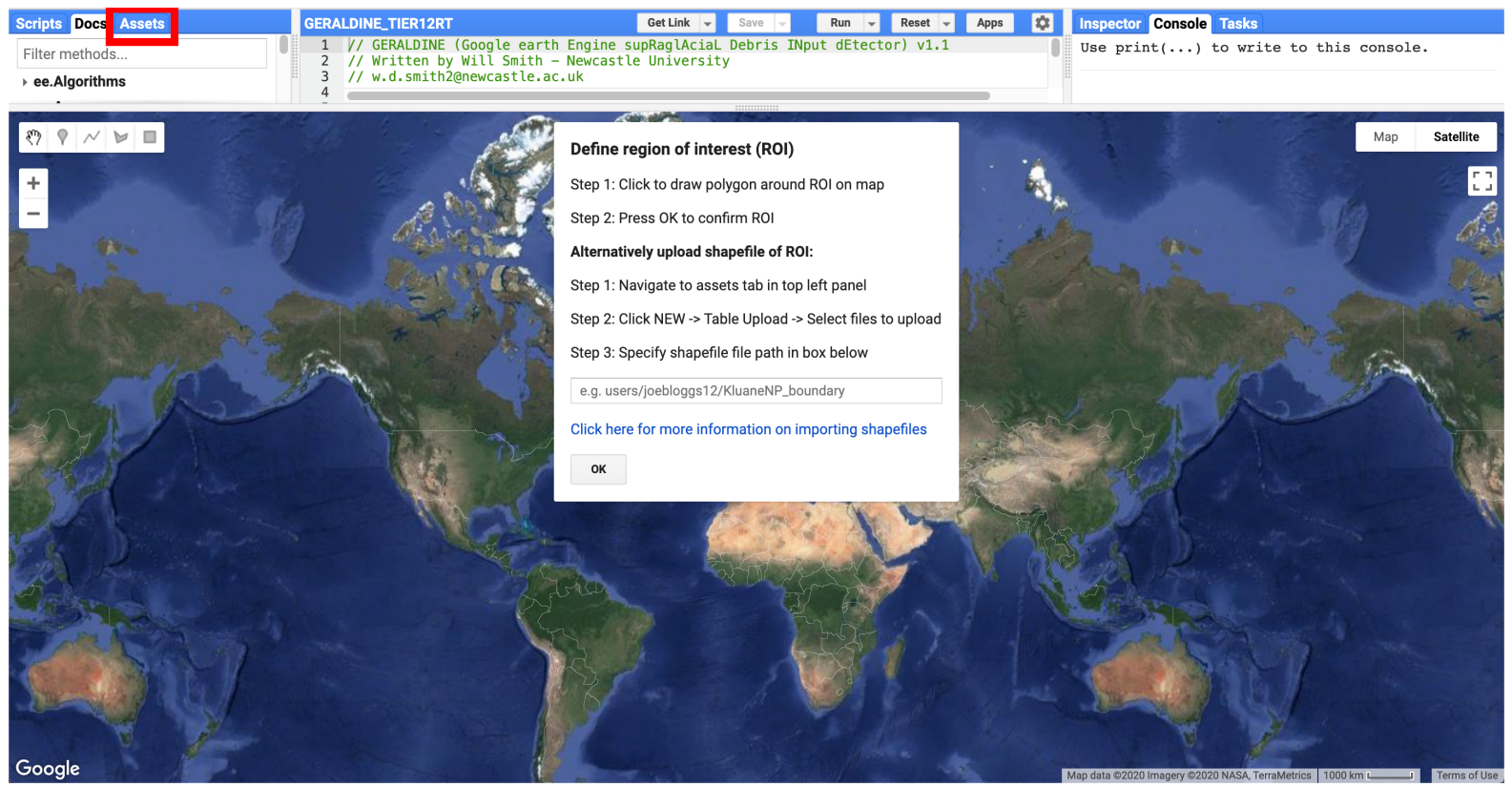

Step 4:

Specify date range from which you want the tool to detect new debris additions and select if you would like to use Tier 2 and/or Real Time Landsat imagery in addition to the default Tier 1 imagery. Tier 2 imagery is useful if minimal Tier 1 imagery is available i.e. in Antarctica, and Real Time imagery should only be used if the event has occurred in the previous 16 days (Note: for Real Time imagery 'End date' must be set as todays date). Tool accuracy and speed is optimum if date ranges are annual or sub-annual and only Tier 1 imagery is utilised. Date must be in the format of Year - Month - Day e.g. 2018-12-22. Press OK once start and end date are defined.

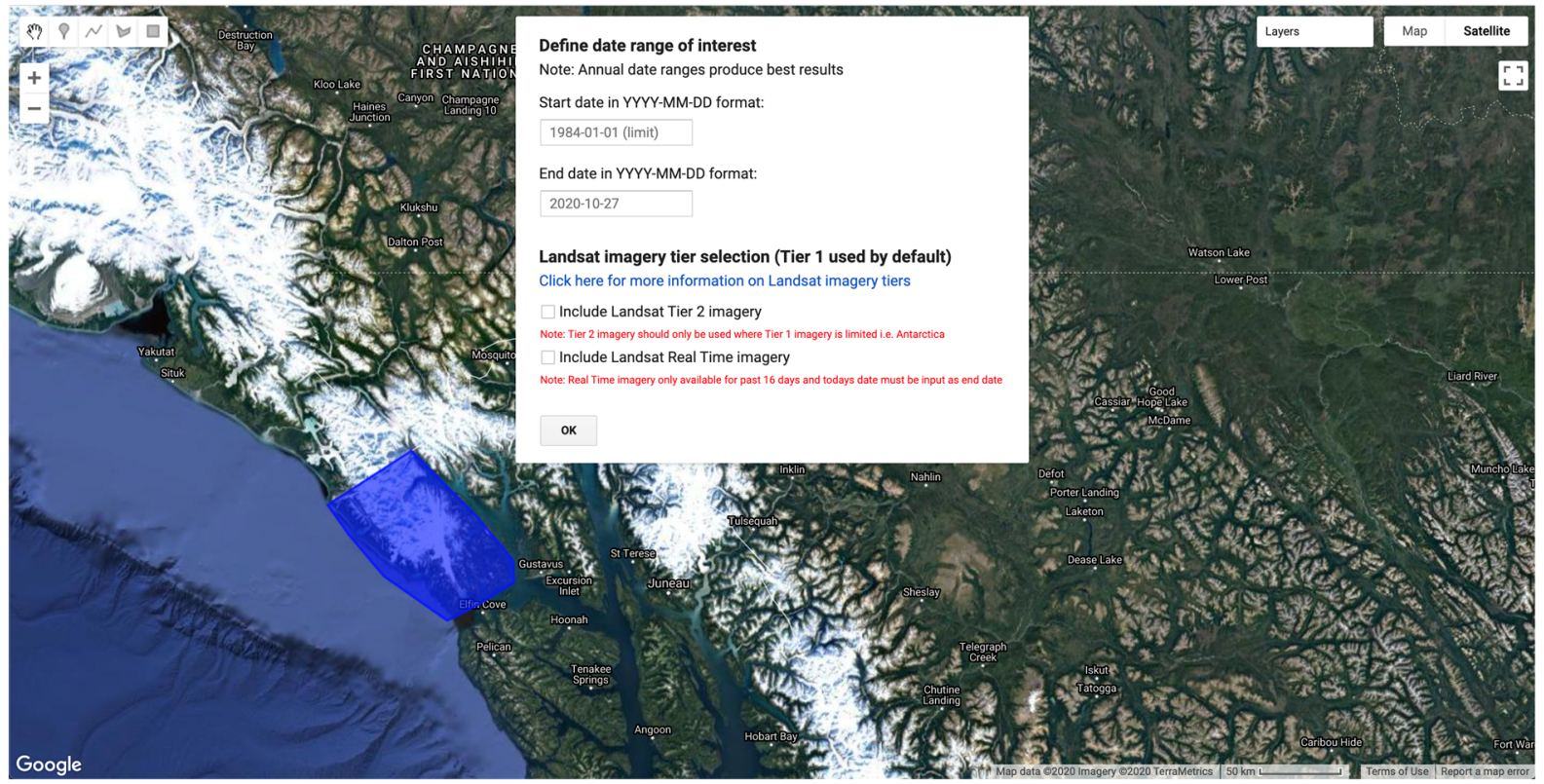

\section{Step 5:}

The tool should display results on the interactive web map (it can take up to 3 minutes for layers to load if analysis is being undertaken on $>800$ images). Two layers are created: a previous year maximum debris cover layer and a new debris additions layer. The user can view and toggle these layers by 
hovering the mouse over the 'Layers' button in the top right hand corner of the map viewer (highlighted by red rectangle in below image). To export the data click on the Export data button.

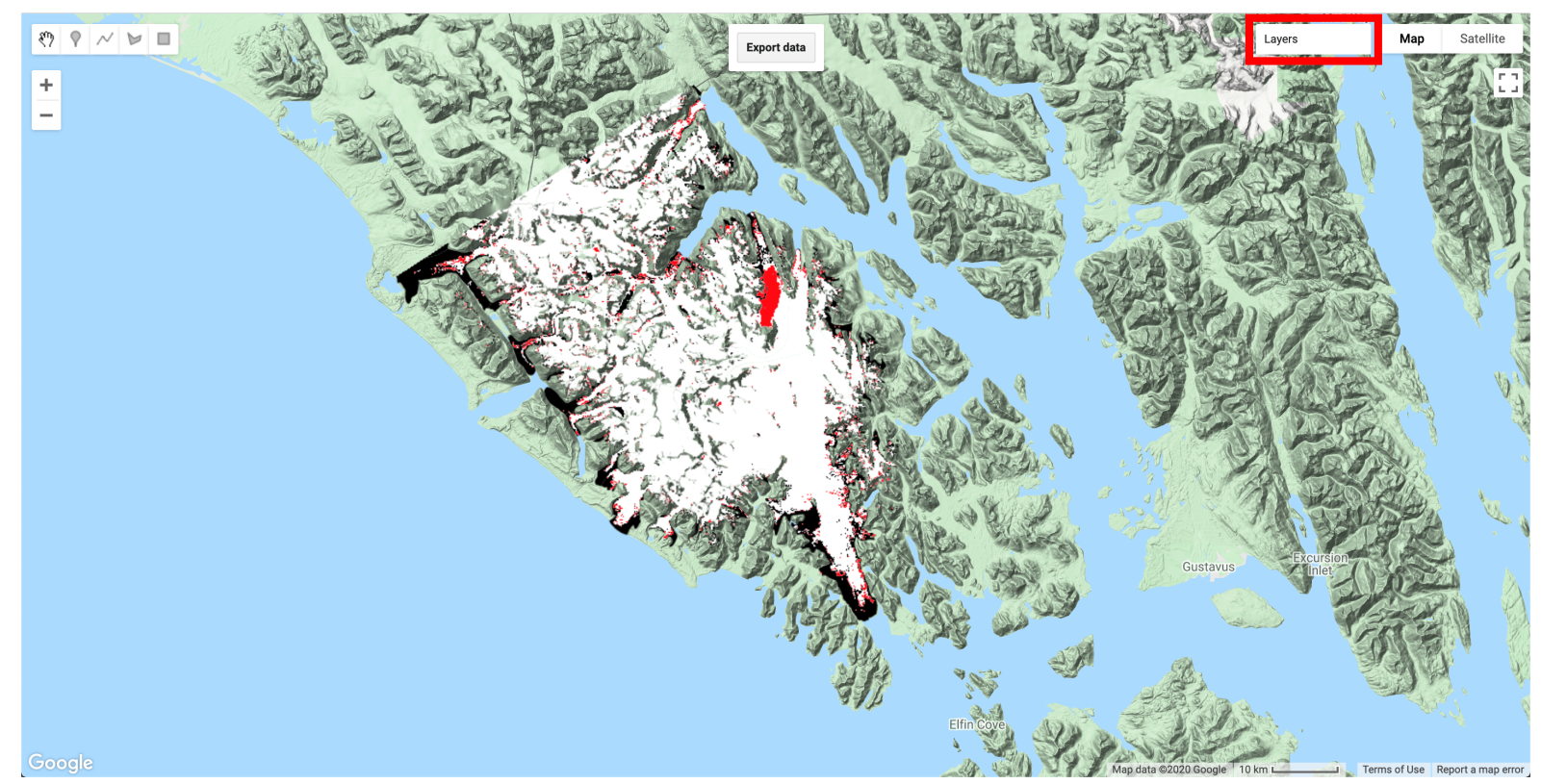

\section{Step 6:}

Instructions are displayed detailing how to export data from GEE. Once you have navigated to the Task tab in the top right hand panel and clicked 'Run' next to the layer you wish to download (note: you do not need to wait for layers to load within GEE before you export). The following window will be displayed (see image below), prompting the user to confirm or alter the filename, confirm the export format (GeoJSON is strongly recommended because it decreases export time), and confirm the save location. Once data is exported, it can be used in a GIS of your choice. Alternatively, you can save your files as an Earth Engine asset, this is particularly useful for your ROI, enabling you to call it in during Step 3, instead of redrawing it every time you use GERALDINE.

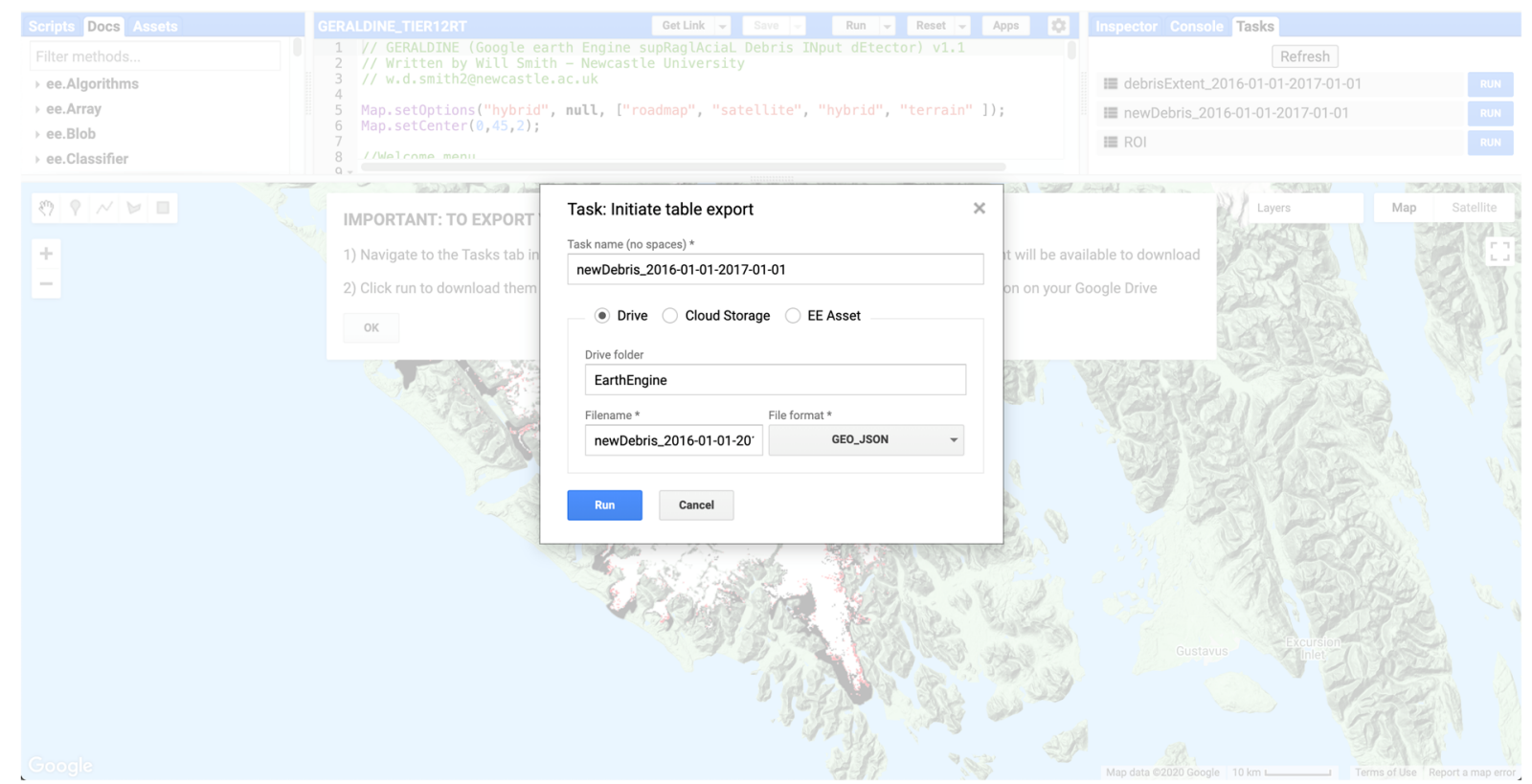




\section{References}

Burton-Johnson, A., Black, M., Peter, T. F. and Kaluza-Gilbert, J.: An automated methodology for differentiating rock from snow, clouds and sea in Antarctica from Landsat 8 imagery: A new rock outcrop map and area estimation for the entire Antarctic continent, Cryosphere, 10(4), 1665-1677, doi:10.5194/tc-10-1665-2016, 2016.

Coe, J. A., Bessette-Kirton, E. K. and Geertsema, M.: Increasing rock-avalanche size and mobility in Glacier Bay National Park and Preserve, Alaska detected from 1984 to 2016 Landsat imagery, Landslides, 15(3), 393-407, doi:10.1007/s10346-017-0879-7, 2018.

Jibson, R. W., Harp, E. L., Schulz, W. and Keefer, D. K.: Large rock avalanches triggered by the M 7.9 Denali Fault, Alaska, earthquake of 3 November 2002, Eng. Geol., 83(1-3), 144160, doi:10.1016/j.enggeo.2005.06.029, 2006.

Pfeffer, W. T., Arendt, A. A., Bliss, A., Bolch, T., Cogley, J. G., Gardner, A. S., Hagen, J.-O., Hock, R., Kaser, G., Kienholz, C., Miles, E. S., Moholdt, G., Mölg, N., Paul, F., Radić, V., Rastner, P., Raup, B. H., Rich, J. and Sharp, M. J.: The Randolph Glacier Inventory: a globally complete inventory of glaciers, J. Glaciol., 60(221), 537-552, doi:10.3189/2014jog13j176, 2014. 